\title{
ПОВНОВАЖЕННЯ КОЛЕГІАЛЬНИХ ОРГАНІВ УПРАВЛІННЯ У ФОРМУВАННІ КОНТИНГЕНТУ УПРАВЛІНСЬКОГО ПЕРСОНАЛУ ВИЩОЇ ЛАНКИ В УНІВЕРСИТЕТІ
}

Статтю присвячено аналізу повноважень колегіальних органів управління університетів у формуванні (відбір, призначення, заохочення, просування, звільнення) управлінського персоналу університету вищої ланки.

Інституційна автономія і принципи діяльності (а саме автономії і самоврядування, поєднання колегіальних та єдиноначальних засад) передбачають підвищення ролі колегіальних органів у всіх аспектах діяльності університетів в Україні, у тому числі й у здійсненні кадрової політики. Відзначено, що в Україні колегіальні органи (а саме вчена рада (основний колегіальний орган управління універcumemy), наглядова рада університету; колегіальний орган громадського самоврядування - загальні збори (конференція) трудового колективу університету) мають повноваження лише ініціювати відкликання керівника університету. Проте реалізація таких повноважень колегіальними органами переважно є номінальною, зважаючи на те, що наглядова рада - частково залежна структура від університету та його керівництва. Адже порядок формування наглядової ради, строк ії повноважень, компетенція та порядок діяльності визначаються статутом університету. $А$ одним із головних завдань є здійснення нагляду за управлінням майном університету; ректор університету створює вчену раду та вносить зміни до ії складу (також може й очолювати ії), затверджує персональний склад конференції трудового колективу університету (та за посадою є членом цього колегіального органу громадського самоврядування).

Виявлено, що в зарубіжних університетах колегіальні органи, а особливо наглядові ради, мають широкі повноваження стосовно формування (відбору, призначення, заохочення, просування, звільнення) управлінського персоналу університету вищої ланки. Вони уповноважені формувати умови відбору, відбирати, приймати на посади кандидатів, контролювати їхню роботу та звільняти із посад (розривати контракт). Рада університету у питаннях кадрової політики виступає здебільшого у ролі дорадчо-консультативного органу.

За результатом дослідження запропоновано розширити повноваження наглядових рад університетів в Україні, наділивши їх повноваженнями з фрормування (призначення, заохочення, просування, звільнення) контингенту управлінського персоналу вищої ланки університетів.

Ключові слова: вчена рада, наглядова рада, конференція трудового колективу, ректор, прорекmop.

Постановка проблеми. Важливою складовою частиною інституційної автономії університетів України $€$ кадрова автономія, яка передбачає самостійний, незалежний і відповідальний добір і розстановку кадрів. Кадрова автономія у діяльності університетів України реалізується на основі принципів автономії і самоврядування та поєднання колегіальних і єдиноначальних засад. Інституційна автономія та зазначені принципи діяльності передбачають підвищення ролі колегіальних органів у всіх аспектах діяльності університету, у тому числі й у здійсненні кадрової політики університету. Тому актуальним $€$ виявлення повноважень колегіальних органів управління університетом щодо формування (відбору, заохочення, просування, звільнення) контингенту управлінського персоналу вищої ланки в університетах України та порівняння їх із повноваженнями колегіальних органів закордонних університетів.
Аналіз останніх досліджень і публікацій. Питання запровадження інституційної автономії розглядали І.В. Богачевська [1], М. Михайліченко [2], оцінювання рівня автономії й ефективності управління та стратегічного розвитку закладу вищої освіти в умовах конкурентного середовища - О.Б Моргулець [3], впливу децентралізації на діяльність закладів вищої освіти - Л. Тупичак [4], удосконалення процесу децентралізації менеджменту закладом вищої освіти - В.Я. Гаврилюк [5] та інші. Однак поза увагою вчених залишилися питання повноважень колегіальних органів університетів щодо формування в університетах контингенту управлінського персоналу вищої ланки.

Мета статті. Виявлення повноважень колегіальних органів управління університетом щодо формування контингенту управлінського персоналу університетів вищої ланки в Україні та порів- 
няння їх із повноваженнями колегіальних органів закордонних університетів.

Виклад основного матеріалу. В Україні до управління університетом залучені такі колегіальні органи: вчена рада (основний колегіальний орган управління університету); наглядова рада університету; колегіальний орган громадського самоврядування - загальні збори (конференція) трудового колективу університету; орган студентського самоврядування університету - загальні збори (конференція) студентів [6, ст. 24, 27, 29; 7, ст. 36, 37].

Вчена рада університету (ії склад затверджується наказом ректора університету) має право вносити подання до вищого колегіального органу громадського самоврядування університету про відкликання керівника університету з підстав, передбачених законодавством, статутом університету чи контрактом [7, ст. 36]. Також вчена рада на основі рекомендації конкурсної комісії університету може таємним голосуванням приймати рішення про обирання на посади заступників керівника університету, проректорів (відповідно до [8]). Ректор університету на основі цього рішення видає накази про призначення своїх заступників (проректорів) [9]. Повноваження вченої ради щодо формування (відбору, заохочення, звільнення) управлінського персоналу вищої ланки досить обмежені. До того ж і перераховані вище повноваження щодо відкликання керівника університету можуть бути лише номінальними, зважаючи на те, що вчена рада створюється наказом ректора і за посадою ректор та проректори входять до неї, а також наказом ректора вносяться зміни до їі складу. Крім того, ректор може також і очолювати вчену раду у разі його обрання таємним голосуванням зі складу вченої ради університету.

Відповідно до Закону України «Про вищу освіту» члени наглядової ради мають право як аналізувати та оцінювати діяльність університету, так і аналізувати й оцінювати діяльність ректора університету, а також вносити подання засновнику університету про заохочення або відкликання ректора університету з підстав, визначених законом [7, ст. 37]. А сама наглядова рада (яка створюється за рішенням засновника університету) має право «сприяти кадровому забезпеченню університету, здійснювати контроль за діяльністю керівництва університету, заслуховувати звіти ректора університету про виконання основних завдань закладу» [10], «вносити вищому колегіальному органу громадського самоврядування та/або засновнику університету подання про відкликання керівника закладу вищої освіти з підстав, передбачених законодавством, статутом закладу вищої освіти, контрактом» [7]. Як бачимо, повноважень щодо формування управлінського персоналу університету вищої ланки у наглядової ради не так і багато. До того ж сильного впливу на кадрову політику щодо управлінського персоналу вищої ланки можна не очікувати, адже наглядові ради не $€$ повністю незалежними структурами від університету та його керівництва, тому що і порядок формування наглядової ради, і строк її повноважень, і компетенція та порядок діяльності визначаються статутом університету. А одним із головних завдань $є$ здійснення нагляду за управлінням майном університету, а вже потім - нагляду за додержанням мети його створення [7, ст. 37].

Конференція трудового колективу університету (далі - КТКУ) має право оцінювати діяльність ректора. Проте, згідно з повноваженнями КТКУ, за результатом такого оцінювання не передбачено ніяких заходів щодо діяльності (чи бездіяльності) ректора. Єдиним впливом $є$ розгляд питання про дострокове припинення повноважень (відкликання) ректора за обґрунтованим поданням наглядової або вченої ради університету (не менш як половиною від статутного складу [7]). Тобто за власною ініціативою КТКУ не може якимось чином (та й відповідно до їі повноважень) коригувати діяльність ректора. На нашу думку, це неможливо ще й тому, що персональний склад КТКУ затверджується ректором, а сам ректор за посадою $є$ членом КТКУ [11].

Орган студентського самоврядування університету щодо управлінського персоналу вищої ланки має лише повноваження погоджувати кандидатуру проректора університету. Повноважень щодо оцінювання діяльності чи ініціювання звільнення не передбачено [7, ст. 40].

Тепер розглянемо повноваження колегіальних органів управління щодо формування контингенту управлінського персоналу вищої ланки в університетах зарубіжних країн. Наприклад, у Республіці Казахстан організаційно-правовою фрормою університету $є$ некомерційне акціонерне товариство. Тому організація управління університетами переходить на так зване «корпоративне управління». Замість наглядових рад створюються ради директорів [12] (уповноважені ради [13]).

Рада директорів визначає кількісний склад, термін повноважень членів виконавчого органу правління (крім голови правління - ректора і члена правління з академічних питань), порядок обрання голови правління - ректора і членів правління (крім члена правління з академічних питань), а також достроково завершує їхні повноваження та притягує до дисциплінарної відповідальності (крім голови правління - ректора і члена правління 3 академічних питань) [14, с. 2, 8], приймає рішення про проведення конкурсу на посади членів правління (крім члена правління з академічних питань), а також визначає умови, дату та місце його проведення, розглядає документи осіб, допущених до участі в конкурсі, програми претендентів на 
посаду голови правління - ректора щодо розвитку університету, за результатом якого формує список рекомендованих осіб для подальшого розгляду республіканською комісією при «уповноваженому органі відповідної галузі» [15, с. 2, 4]. За результатом проведення співбесіди таємним голосуванням визначає кандидатуру на посаду члена правління, визначає термін її повноважень (крім члена правління з академічних питань) [15, с. 10, 11].

Вчена рада (сенат), виборний колегіальний орган (склад якого затверджує голова правління ректор університету (президент), який також і очолює вчену раду) не має повноважень щодо формування контингенту управлінського персоналу вищої ланки в університетах [16, с. 23-24; 17]. Вони лише «заслуховують річний звіт президента про проведену роботу, а також обговорюють подані ректоратом звіти про проведену роботу, виконання стратегічного плану і його індикаторів» [17].

В університетах Нідерландів в основу організації системи управління університетами покладено «корпоративне управління», згідно з яким наглядова рада (raad van toezicht) університету призначає, звільняє членів виконавчої ради (college van bestuur) із узгодженням із радою університету (universiteitsraad) [18, ст. 9.3.2], визначає розмір оплати їхньої праці, контролює дотримання ними повноважень [19], щонайменше раз на рік оцінює якість діяльності членів виконавчої ради (розглядає питання їхньої діяльності та робить відповідні висновки за результатами індивідуальних співбесід із членами виконавчої ради), укладає контракти із членами виконавчої ради, визначає їхні посадові повноваження й обов'язки, дає їм дозвіл на зайняття оплачуваних та неоплачуваних додаткових посад [20, с. 3, 4], визначає умови найму (відбору та призначення) членів виконавчої ради [21, с. 14]. Виконавча рада університету здійснює керівництво справами університету («відповідає за управління та адміністрування університету в цілому» [18, ст. 9.2.1]). До її складу якої входить «максимум три члени, включаючи ректора (rector magnificus)» [18, ст. 9.3.1] (rector magnificus - особа академічної спільноти, яка несе відповідальність за наукові дослідження, освіту та студентів в університеті [22; 23], кандидатів на посаду пропонує рада деканів (raad van decanen) зі складу професорів університету [24, с. 2]).

Рада університету $є$ головним колегіальним органом університету, як уже було зазначено вище, дає згоду на призначення чи звільнення наглядовою радою членів виконавчої ради, вносить пропозицію Міністру освіти щодо призначення кандидатури одного із членів наглядової ради університету, вносить пропозиції наглядовій раді щодо профілів для призначення членів виконавчої ради [25, с. 5, 6, 7]. Студенти залучені до всіх питань, що розглядаються радою універ- ситету, адже половину складу ради університету становлять студенти, які й обираються студентами університету [26].

Висновки і пропозиції. На основі проведеного аналізу можна зробити висновки.

У зарубіжних університетах управління університетом реалізується на основі принципу колегіальності. Всі управлінські структури здійснюють управління на основі колегіального прийняття рішень.

В університетах Нідерландів наглядові ради виступають у ролі роботодавців для управлінського персоналу вищої ланки університету. Вони уповноважені формувати умови відбору, відбирати, приймати на посади кандидатів, контролювати їхню роботу та розривати контракт. Рада університету у питаннях кадрової політики виступає здебільшого у ролі дорадчо-консультативного органу.

В університетах України, як і в зарубіжних університетах, діють колегіальні органи управління. Однак, на відміну від колегіальних органів управління зарубіжних університетів, повноцінно у процесі формування контингенту управлінського персоналу вищої ланки університету вони участі не беруть. Їхні повноваження обмежуються переважно виробленням пропозиції роботодавцю про звільнення управлінського персоналу.

В Україні слід розширити повноваження наглядових рад університетів, наділивши їх повноваженнями з формування (призначення, заохочення, просування, звільнення) контингенту управлінського персоналу вищої ланки в університетах.

\section{Список використаної літератури:}

1. Богачевська І.В. Автономізація університетів як складова реформа вищої освіти України: аналітична записка. URL: https://niss. gov.ua/doslidzhennya/gumanitarniy-rozvitok/ avtonomizaciya-universitetiv-yak-skladovareformi-vischoi.

2. Михайліченко М. Автономія університетів як необхідна умова децентралізації державної влади в освіті України. Нова парадигма. 2017. Вип. 132. С. 33-44. URL: http://nbuv.gov.ua/ UJRN/Nopa_2017_132_6.

3. Моргулець О.Б. Управління вищим навчальним закладом як суб'єктом ринку : монографія. К. : КНУТД, 2017. 454 с. URL: https://er.knutd. edu.ua/bitstream/123456789/9467/2/Morgulets_ Mono_Titul_Zmist_Vstup.pdf.

4. Тупичак Л. Особливості децентралізації управління освітньою системою як шлях до модернізації вищої освіти в Україні. Ефективність державного управління. 2017. Вип. 4 (53). Ч. 1. C. 56-62. URL: http://www.Ivivacademy.com/ vidavnitstvo_1/edu_53/fail/8.pdf.

5. Гаврилюк В.Я. Децентралізація менеджменту вищих навчальних закладів як спосіб підви- 
щення ефрективності їх функціонування. Вісник Національного університету «Львівська політехніка». 2012. № 727. С. 16-23. URL: http:// ena.Ip.edu.ua/bitstream/ntb/13830/1/4_16-23_ Vis_727_Menegment.pdf.

6. Про освіту : Закон України від 05.09.2017 № 2145-VIII. URL: https://zakon.rada.gov.ua/ laws/show/2145-19\#Text.

7. Про вищу освіту : Закон України від 01.07.2014 № 1556-VII (у редакції від 23.04.2021, підстава - 1357-XI). URL: https://zakon.rada.gov. ua/laws/show/1556-18\#Text.

8. Рекомендації щодо проведення конкурсного відбору при заміщенні вакантних посад науково-педагогічних працівників та укладання 3 ними трудових договорів (контрактів), затверджені наказом МОН України від 05.10.2015 № 1005 (у редакції наказу МОН України від 26.11.2015 № 1230). URL: https://zakon.rada. gov.ua/rada/show/v1005729-15\#Text.

9. Про призначення проректора : накази від 09.09.2019 № 2987л, № 2988ת, № 2989ת, № 2990л / Національний технічний університет України «КП। імені Ігоря Сікорського». URL: https://ae.fea.kpi.ua/ae-files/doc/nakaz/ 20190909_N2987-2990.pdf/

10.Статут Національного технічного університету України «Київський політехнічний інститут імені Ігоря Сікорського» (нова редакція), затверджений наказом МОH України від 02.11.2016 № 1308. URL: https://kpi.ua/statute\#_ Toc468289890.

11. Статут Сумського державного університету державної форми власності. 25 c. URL: https:// normative.sumdu.edu.ua/index.php?task= getfile \&tmpl=component $\& i d=802 \mathrm{fff} 39-0 \mathrm{fb} 2$ e011-9640-001a4be6d04a\&kind $=1$.

12.Об образовании : Закон Республики Казахстан от 27.07.2007 № 319-III. URL: https://zakon. uchet.kz/rus/docs/Z070000319

13.Устав Международного казахско-турецкого университета имени Ходжи Ахмета Ясави. 18 c. URL: http://ayu.edu.kz/about/management/ New\%20Folder/ustav-2019.pdf.

14.Положение о Правлении Некоммерческого акционерного общества «Казахский национальный университет имени аль-Фараби», утверждено решением Совета директоров НАО «КНУ имени аль-Фараби» 16.06.2021, протокол № 4. Алматы, 2021. 12 c. URL: https:// www.kaznu.kz/content/files/pages/folder23065/ Положение о Правлении.pdf.

15.Порядок отбора и назначения Председателя Правления - Ректора и избрания членов Правления Некоммерческого акционерного общества «Казахский национальный университет имени аль-Фараби», утверждено решением Совета директоров НАО «КНУ имени
аль-Фараби» 14.01.2021, протокол № 1, (с изменениями от 10.03.2021, протокол № 3 , от 16.06.2021, протокол № 4). 14 c. URL: https:// www.kaznu.kz/content/files/ pages/folder23065/ Порядок отбора июнь 2021.pdf.

16.Устав Некоммерческого акционерного общества «Казахский национальный университет имени аль-Фараби», утвержден приказом Председателя Комитета государственного имущества и приватизации Министерства финансов Республики Казахстан от 25.08.2020 № 512. Нур-Султан, 2020. 37 c. URL: https:// www.kaznu.kz/content/files/pages/ folder23065/ ҚазҰУ КЕАҚ Жарғысы-Уставрdf.pdf.

17.Деятельность Сената университета (Ученого совета) / Университет им. Ахмета Ясави. URL: https://ayu.edu.kz/ru/senate.

18. Wet op het hoger onderwijs en wetenschappelijk onderzoek : Wet van 08.10.1992. URL: https:// wetten.overheid.nl/BWBR0005682/2020-08-01.

19.Profielschets Raad van Toezicht Universiteit Leiden / Universiteit Leiden. URL: https://www. universiteitleiden.nl/binaries/content/assets/ algemeen/over-ons/profielschets-raad-vantoezicht-universiteit-leiden.pdf.

20. Reglement van de Raad van Toezicht van de Universiteit Leiden / Universiteit Leiden. URL: https://www.organisatiegids.universiteitleiden.nl/ reglementen/algemeen/reglement-van-de-raadvan-toezicht-van-de-universiteit-leiden.

21. Code goed bestuur universiteiten. Vastgesteld op 22 november 2019 / VSNU (verening van universiteiten; association of universities the Netherland). URL: https://www.vsnu.nl/files/ documenten/Domeinen/Governance/VSNU_ CodeGoedBestuur_Nederlands_definitief_ 11122019.pdf.

22.Academic ranks in the Netherlands. URL: https:// en.wikipedia.org/wiki/Academic_ranks_in_the _ Netherlands.

23.Profile for new Rector Magnificus / Utrecht University. URL: https://www.uu.nl/en/news/profile-for-new-rector-magnificus.

24. Management and Administration Regulation of Leiden University / University Leiden. 16 p. URL: https://www.organisatiegids.universiteitleiden.nl/ binaries/content/assets/ul2staff/reglementen/ bestuur-en-organisatie/management-and-administration-regulation-of-leiden-university.pdf.

25. Regulations relating to the University Council / Universiteit Leiden. 13 p. URL: https://www.organisatiegids.universiteitleiden.nl/binaries/content/ assets/ ul2staff/reglementen/bestuur-en-organisatie/reglement-universiteitsraad-eng.pdf.

26. University Council / Universiteit Leiden. URL: https://www.universiteitleiden.nl/en/about-us/ management-and-organisation/university-council. 


\section{Zhabenko O. Powers of collegial management bodies in the formation of senior management staff continent at the university \\ The article is devoted to the analysis of the powers of collegial governing bodies of universities in the} formation (selection, appointment, incentive, promotion, dismissal) of senior management staff of the university.

Institutional autonomy and principles of activity (namely autonomy and self-government, a combination of collegial and undivided authority) provide for increasing the role of collegial bodies in all aspects of the universities activity in Ukraine, including the implementation of personnel policy. It was noted that in Ukraine collegial bodies (namely: the academic council (the main collegial governing body of the university); the supervisory board of the university; the collegial body of public self-government - general meeting (conference) of the university staff) have the authority only to initiate the recall of the head of the university. However, the realization of such powers by collegial bodies is mostly nominal, given that the supervisory board is partly dependent on the university and its management. After all the procedure for forming the supervisory board, the term of its powers, competence and order of activities are determined by the university statutes. And one of the main tasks is to supervise at the management of university property; the rector of the university creates an academic council and makes changes to its composition (may also head it), approves the personal composition of the conference of the university staff (and ex officio is a member of this collegial body of public self-government).

It was found that in foreign universities collegial bodies, and especially supervisory boards, have broad powers to form (selection, appointment, incentive, promotion, dismissal) senior management staff of the university. They are authorized to formulate the conditions of selection, select, accept candidates for positions, control their work and dismiss them (terminate the contract). The university council in matters of personnel policy acts mainly as an advisory-consultative body.

As a result of the study, to expand the powers of supervisory boards of universities in Ukraine, giving them the power to form (appoint, incentive, promotion, dismissal) of senior management staff contingent of universities was proposed.

Key words: academic council, supervisory board, conference of the university staff, rector, vice-rector. 